\title{
Influence of glycogen level on physical characteristics of goat meat
}

\author{
Shahnawaz Fazlani ${ }^{1 *}$, Asad Ali Khaskheli ${ }^{2}$, Abdul Samad Magsi ${ }^{1}$, Gul \\ Bahar Khaskheli ${ }^{1}$, Ghulam Shabir Barham ${ }^{1}$ and Haque Nawaz \\ Fazlani $^{3}$ \\ 1. Department of Animal Products Technology, Sindh Agriculture University, Tando Jam-Pakistan \\ 2. Department of Animal Nutrition, Sindh Agriculture University, Tando Jam-Pakistan \\ 3. Faculty of Animal Husbandry and Veterinary Sciences, Sindh Agriculture University, Tando Jam-Pakistan \\ *Corresponding author's email:fazlanishahnawaz@gmail.com \\ Citation \\ Shahnawaz Fazlani, Asad Ali Khaskheli, Abdul Samad Magsi, Gul Bahar Khaskheli, Ghulam Shabir Barham \\ and Haque Nawaz Fazlani. Influence of glycogen level on physical characteristics of goat meat. Pure and \\ Applied Biology. Vol. 8, Issue 4, pp2409-2419. http://dx.doi.org/10.19045/bspab.2019.80186

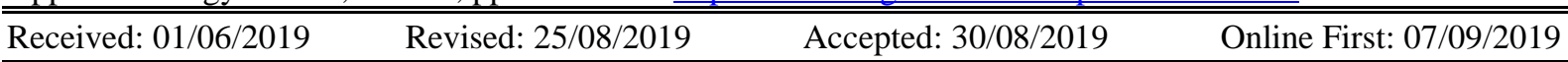

\section{Abstract}

Current study was carried out to evaluate the glycogen level and its influence on physical and sensory characteristics of goat meat of different age groups such as A (6-12 m; age), B (13-18 $\mathrm{m}$; age) and C (>18 m; age) slaughtered at Tando Jam market during the year 2012. Goat meat of all three age groups were examined for glycogen level, physical characteristics such as $\mathrm{pH}$ value, water holding capacity (WHC), cooking loss (CL), drip loss (DL). Average glycogen level, CL, WHC, DL and $\mathrm{pH}$ value of goat meat of group A and B were statistically nonsignificant $(\mathrm{P}>0.05)$. But these characteristics of both groups (A and $\mathrm{B}$ ) were significantly different from that of group $\mathrm{C}$ goat meat. The relationship of glycogen $\mathrm{v} / \mathrm{s} \mathrm{pH}$ remained negative in group A and B, while positive in group C. WHC of goat meat of group A and B was inversely related with glycogen level but statistically not countable $(\mathrm{P}>0.05)$. The influence of glycogen on CL of group A was found to be inverse and in group B and C, it was positive. Further, significant $(\mathrm{P}<0.05)$ relationship between glycogen and $\mathrm{CL}$ was found to be in group B. The DL was directly related with glycogen level, but their relationship was not statistically countable $(\mathrm{P}>0.05)$. Despite, the goat meat of group A and B were found to be statistically similar in physical characteristics, the results varied slightly, and group B goat meat concluded to be better among all groups.

Keywords: Cooking; Drip loss; Glycogen; Palatability

\section{Introduction}

In Pakistan, goats are usually reared for meat and hair production, even though some breeds are fairly good milk producers. However, none of breeds seems to have been specially developed as a dairy or meat type, but served as multi-purpose animals with low performance level [1]. It has been found that goats of very young age (kids), old, culled, diseased or injured are usually used for the production of goat meat. Moreover, its processing has always been in the hands of butchers with very little knowledge. The production and processing conditions have significant impact on glycogen level that may play very important role in the quality of meat. Glycogen is principal storage form of carbohydrate in animal species and it is more or less abundant in nearly all types of animal cells [2]. There are two largest deposit sites of glycogen storage i.e. the liver, that functions to maintain the blood glucose levels within the required range [3] 
and the muscle that functions solely as a fuel reserve for the generation of Adenosine Triphosphate (ATP) needed in muscle contraction [2].

Muscles that produce meat with a normal $\mathrm{pH}$ contain about 10-20 mg (1-2\%) glycogen. However, acidification that occurs in muscle post-mortem may breakdown glycogen to lactic acid. If it is depleted by chronic (long term) stress before slaughter then less lactic acid can be formed and the meat does not acidify normally, resulting with high $\mathrm{pH}$. Reduction in the glycogen $<8 \mathrm{mg}$ per gram results in elevation of ultimate $\mathrm{pH}$, and the greater the reduction, the higher the $\mathrm{pH}$ [4]. Among these, the physical attributes like water holding capacity, cooking loss, drip loss and sensory properties like colour, taste, tenderness are important characteristics affecting meat acceptability $[5,6,7,8]$. Ante-mortem depletion of glycogen may cause meat quality defects which are prime important for consumers when it comes to making purchasing decisions. Dark Firm Dry (DFD) condition in meat is one of the major quality problems facing the meat industry.

Firstly, the DFD condition may affect the colour of meat which either became too pale or too dark that is discriminated against the preference to normal colour of meat [9]. Secondly, the DFD meat has poor processing characteristics with slow or uneven formation of cured meat pigments resulting poor flavour development [10]. Thirdly, the DFD meat has a high spoilage potential, so does not keep well and has a short shelf life [11]. Another, major factor that affect the eating quality of meat is the nutritional status of goats with breed and diet having an impact on flavour [12, 13]. While from growth to slaughter, there are some other factors such as stress, ageing, breed and age that may also affect the quality of meat. Meat quality is combination of physical, chemical and sensory attributes which are important for consumers. Goat meat has gained popularity especially in the developed countries and its quality is well studied. However, in developing countries like Pakistan, goat meat is still processed under traditional systems, and needs lot of attentions in term of its quality $[14,15]$. Thus in regards to quality of meat, present study has been conducted to observe the influence of glycogen on physical characteristics of goat meat.

\section{Materials and methods}

\section{Experimental procedure}

Experiment was conducted to observe the level of glycogen and its influence on physical characteristics of goat meat slaughtered at Tando Jam market. Goat meat was categorized into three age groups and accredited with A (6 to $12 \mathrm{~m}$; age), B (13 to $18 \mathrm{~m}$; age) and $\mathrm{C}(>18 \mathrm{~m}$; age) codes. A total of thirty $(n=30)$ goat meat samples i.e. 10 samples for each group were examined for glycogen; physical characteristics like $\mathrm{pH}$, water holding capacity, cooking loss, drip loss at the dairy and meat chemistry laboratory, Department of Animal Products Technology, Faculty of Animal Husbandry and Veterinary Sciences, Sindh Agriculture University, Tando Jam.

\section{Glycogen level}

The method reported by [16] was used to determine the glycogen level in meat. Meat sample was placed in a centrifuge tube together with $5 \mathrm{ml}$ of de-proteinizing solution, Trichloroacetic acid $(5 \mathrm{~g})$ and $\mathrm{Ag}_{2} \mathrm{SO}_{4}$ (100mg) and make up to $100 \mathrm{ml}$ with distilled water. The tubes with samples were placed in boiling water bath for 15 min and thereafter cooled in running water and centrifuged at $3000 \mathrm{rmp}\left(4^{0} \mathrm{C}\right)$ for 5 min. One $\mathrm{ml}$ of clear supernatant and $3 \mathrm{ml}$ of $\mathrm{H}_{2} \mathrm{SO}_{4}$ was taken in a wide test tube and mixed by vigorous shaking. The mixture was heated in a boiling water-bath for exactly $6 \mathrm{~min}$ and subsequently cooled in running tap water. The intensity of color was measured through spectrophotometer at $520 \mathrm{~m} \mu$ and the glycogen concentration was recorded from a standard curve in term of glucose equivalents.

\section{Physical analysis of meat samples}




\section{pH Value}

$\mathrm{pH}$ values of goat meat samples were examined according the method as reported by [17]. Meat sample (10g) homogenized in distilled water $(90 \mathrm{ml})$ was transferred into the beakers, and electrodes along with temperature probe was inserted to sample. The constant reading appeared on $\mathrm{pH}$ meter base was noted and recorded as $\mathrm{pH}$ value of goat meat.

\section{Water-holding capacity (WHC)}

The method reported by [18] was used to determine the WHC of goat meat. Approximately $8 \mathrm{~g}$ meat sample was placed in a centrifuge tube together with $0.6 \mathrm{M}$ $\mathrm{NaCl}$ solution $(12 \mathrm{ml})$. The tube was centrifuged $\left(4^{0} \mathrm{C}\right)$ at $10,000 \mathrm{rmp}$ for $15 \mathrm{~min}$, and the supernatant was decanted and measured. The difference between the volume of $\mathrm{NaCl}(0.6 \mathrm{M})$ used and supernatant will be recorded as WHC.

\section{Cooking loss}

Cooking loss of goat meat was measured according to the method as reported by [19]. Meat sample $(20 \mathrm{~g})$ was placed in a polyethylene bag and heated for $1 \mathrm{hr}$ in a water bath at $80^{\circ} \mathrm{C}$ to achieve an internal temperature of $72^{\circ} \mathrm{C}$. Cook out was drained and cooked mass was cooled and weighed to determine the weight loss using the following formula.

$$
\text { Cooking loss } \%=\frac{\text { Actual weight-Cooked mass weight }}{\text { Actual weight }} \times 100
$$

\section{Drip loss}

Drip loss was measured as described by [20]. Goat meat sample (50 g) was placed at $4^{\circ} \mathrm{C}$ for $24 \mathrm{hrs}$ in a refrigerator under polyethylene bag with sealed covers. After
24 hrs the sample was wiped and dried with filter paper and weighed. The difference among actual weight of sample and weight after refrigeration was assumed as drip loss.

$$
\text { Drip loss } \%=\frac{\text { Actual weight-Weight after refrigeration }}{\text { Actual weight }} \times 100
$$

\section{Statistical Analysis}

The data was subjected to analysis of variance (ANOVA) on different age groups and in case of significant differences appeared among the means, the least significant differences were computed using computer package i.e. Student Edition of Statistics (SXW) (Copyright 2005, Analytical Software, USA).

\section{Results}

\section{Glycogen level in goat meat}

Goat meat samples were analyzed for glycogen level, and the results are shown in (Figure 1). The concentration of glycogen varied between 14.57 to $21.95,14.74$ to 23.21 and 7.96 to $13.34 \mathrm{mg} / \mathrm{g}$ in meat of goat with age group of $\mathrm{A}, \mathrm{B}$ and $\mathrm{C}$, respectively. However, glycogen level was found to be slightly higher in group B $(17.79 \pm 0.85 \mathrm{mg} / \mathrm{g})$ compared to that of group A (17.55 $\pm 0.75 \mathrm{mg} / \mathrm{g})$. The differences among them were statistically non-significant $(\mathrm{P}>0.05)$. Whilst the glycogen level in meat of older group i.e. group C $(9.56 \pm 0.49 \mathrm{mg} / \mathrm{g})$ was found to be significantly $(\mathrm{P}<0.05)$ lower than that of both groups $\mathrm{A}$ and $\mathrm{B}$.

Influence of glycogen level on physical characteristics of goat meat pH value

$\mathrm{pH}$ value of goat meat was analyzed, and results are presented in (Figure 2). The results indicated that the minimum $\mathrm{pH}$ value of goat meat was observed as 5.80, 5.82 and 5.96, whilst the maximum was recorded as 6.64, 6.47 and 6.92 for group A, $\mathrm{B}$ and $\mathrm{C}$, respectively. However, the mean $\mathrm{pH}$ value was found to be remarkably $(\mathrm{P}<0.05)$ higher in group $\mathrm{C}(6.48 \pm 0.08)$ compared to that of both group A $(6.05 \pm$ 
$0.07)$ and $\mathrm{B}(6.12 \pm 0.08)$. It was further noted that the differences in $\mathrm{pH}$ values between group A and B were statistically non-significant $(\mathrm{P}>0.05)$.

\section{Water holding capacity (WHC)}

Water holding capacity of goat meat was examined, and results are depicted in (Figure 3). Water holding capacity of goat meat was evaluated in a range of 17.92 and $26.25 \%$ for group A, 17.92 and $32.08 \%$ for group B and 25.25 and $37.90 \%$ for group C. The average WHC of meat was comparatively higher in group C (30.81 \pm $1.16 \%$ ) than that of both groups i.e. B $(24.20 \pm 1.29 \%)$ and $\mathrm{A}(22.02 \pm 0.77 \%)$. However, the water holding capacity of goat meat between group $\mathrm{A}$ and $\mathrm{B}$ was found to be relatively similar $(\mathrm{P}>0.05)$.

\section{Cooking loss}

Cooking loss of goat meat of different age groups was analyzed, and results are shown in (Figure 4). Cooking loss in goat meat of group A varied between 31.75 to $38.25 \%$ and in group B in between 30.52 to $42.80 \%$, whilst it ranged between 22.50 to $32.00 \%$ in group $\mathrm{C}$. The average cooking loss in goat meat of group A $(34.82 \pm 0.62 \%)$ and B $(35.46 \pm 1.21 \%)$ was relatively similar $(\mathrm{P}>0.05)$. However, in both of these groups (i.e. A and B) the cooking loss was remarkably higher $(\mathrm{P}<0.05)$ contrast to that of group C $(28.02 \pm 0.83 \%)$.

\section{Drip loss}

Drip loss in goat meat of different age groups was analyzed, and results are illustrated in (Figure 5). A wide variation was observed in drip loss of meat within same age group. It was found that drip loss in goat meat of group A ranged between 2.10 to $4.27 \%$, and it varied between 1.36 to 4.70 in group B, whilst it was in between 1.70 to 3.70 in goat meat of group C. It was further observed that although the average drip loss in goat meat was found to be slightly varied between group A (2.84 \pm
$0.19 \%), \mathrm{B}(2.88 \pm 0.39 \%)$ and C (2.48 \pm $0.19 \%$ ), statistical analysis (ANOVA) showed non-significant difference $(\mathrm{P}>0.05)$ among them.

Pearson correlation between glycogen and physical characteristics of goat meat Influence of glycogen on physical characteristics of goat meat was examined, and results are presented in (Table 1). It was observed that glycogen has no any significant $(\mathrm{P}>0.05)$ influence on cooking loss, drip loss, water holding capacity and $\mathrm{pH}$ value of goat meat of age group 6-12 m, 13-18 $\mathrm{m}$ and $>18 \mathrm{~m}$ except on cooking loss of goat meat of age group 13-18 m, where significant $(\mathrm{P}<0.05)$ relationship was found to be among glycogen and cooking loss. Further, it was noted that the glycogen was positively correlated with cooking loss of goat meat of age group 13-18 $\mathrm{m}$ and $>18 \mathrm{~m}$ but negatively correlated with age group 6$12 \mathrm{~m}$. The relationship among them was modest $(r=0.6407)$, weak $(r=0.2353)$ and weak $(r=-0.3658)$, respectively. Moreover, positive correlation was observed between the glycogen and drip loss of goat meat of age group 6-12 $\mathrm{m}, 13-18$ and $>18 \mathrm{~m}$. The influence of glycogen on drip loss was found to be very weak in goat meat of age group 6-12 $\mathrm{m}(\mathrm{r}=0.0846)$ and $>18 \mathrm{~m}(\mathrm{r}=$ $0.0236)$, while it was noted weak ( $\mathrm{r}=$ 0.2780 ) in case of age group 13-18 $\mathrm{m}$. The relationship was found to be negative between glycogen and WHC of goat meat of different age groups. However, this relationship was weak in case of goat meat of age group 6-12 $\mathrm{m}(\mathrm{r}=-0.2915)$ and very weak in age group of 13-18 $\mathrm{m}(\mathrm{r}=-0.0542)$ and $>18 \mathrm{~m}(\mathrm{r}=-0.0157)$. The influence of glycogen on $\mathrm{pH}$ value of goat meat remained negative in age group 6-12m $(\mathrm{r}=$ -0.1135; weak) and 13-18 $\mathrm{m}(\mathrm{r}=-0.1775$; weak), while it was positive incase of age group $>18 \mathrm{~m}(\mathrm{r}=0.0243$; very weak). 


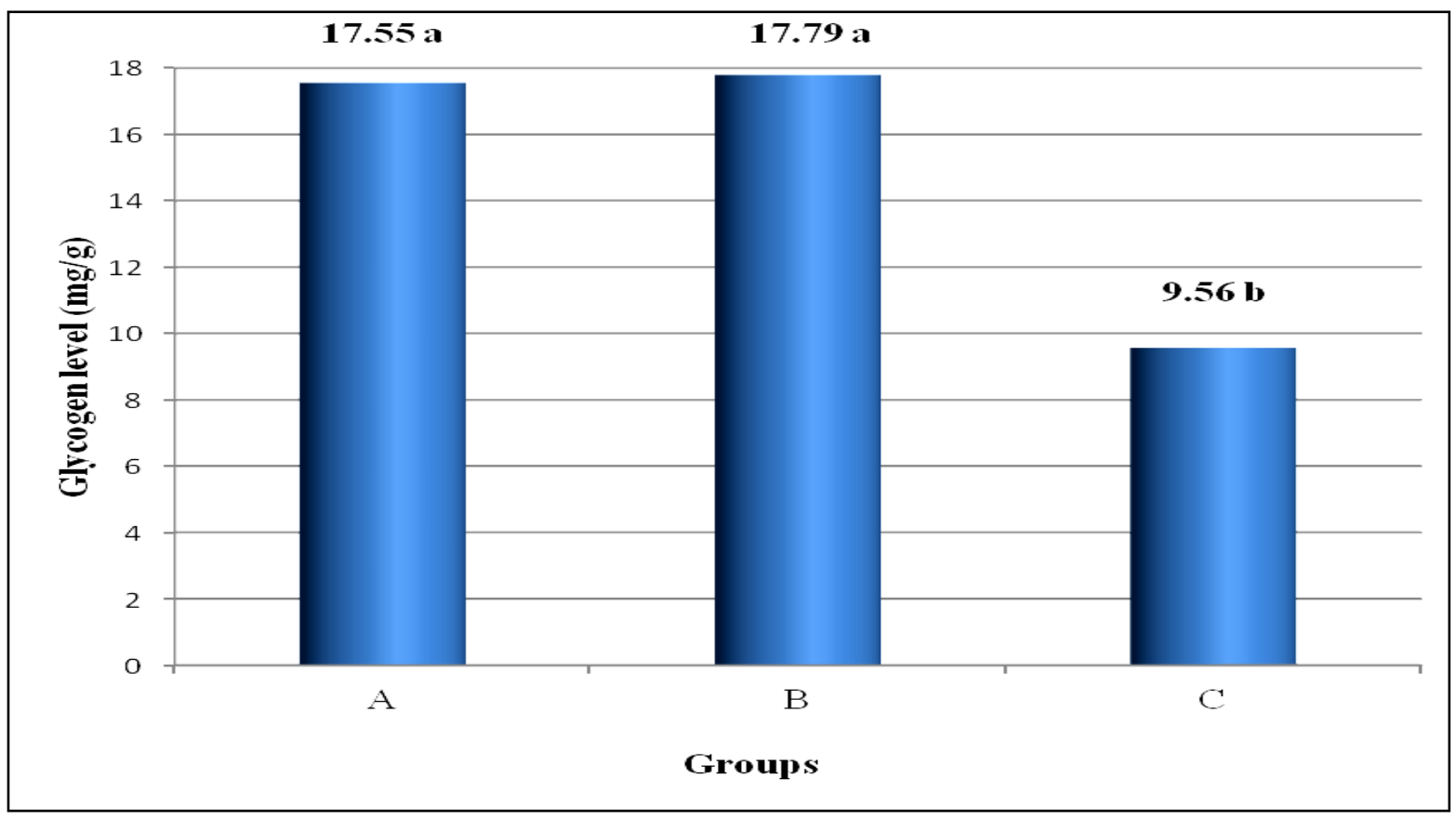

$\operatorname{LSD}(0.05)=2.088, \mathrm{SE} \pm=1.016$, Group $\mathrm{A}=$ Goat meat of age group 6-12 months, Group B $=$ Goat meat of age group 13-18 months, Group C = Goat meat of age group $>18$ months

\section{Figure 1. Glycogen level (mg/g) of goat meat of different age groups}

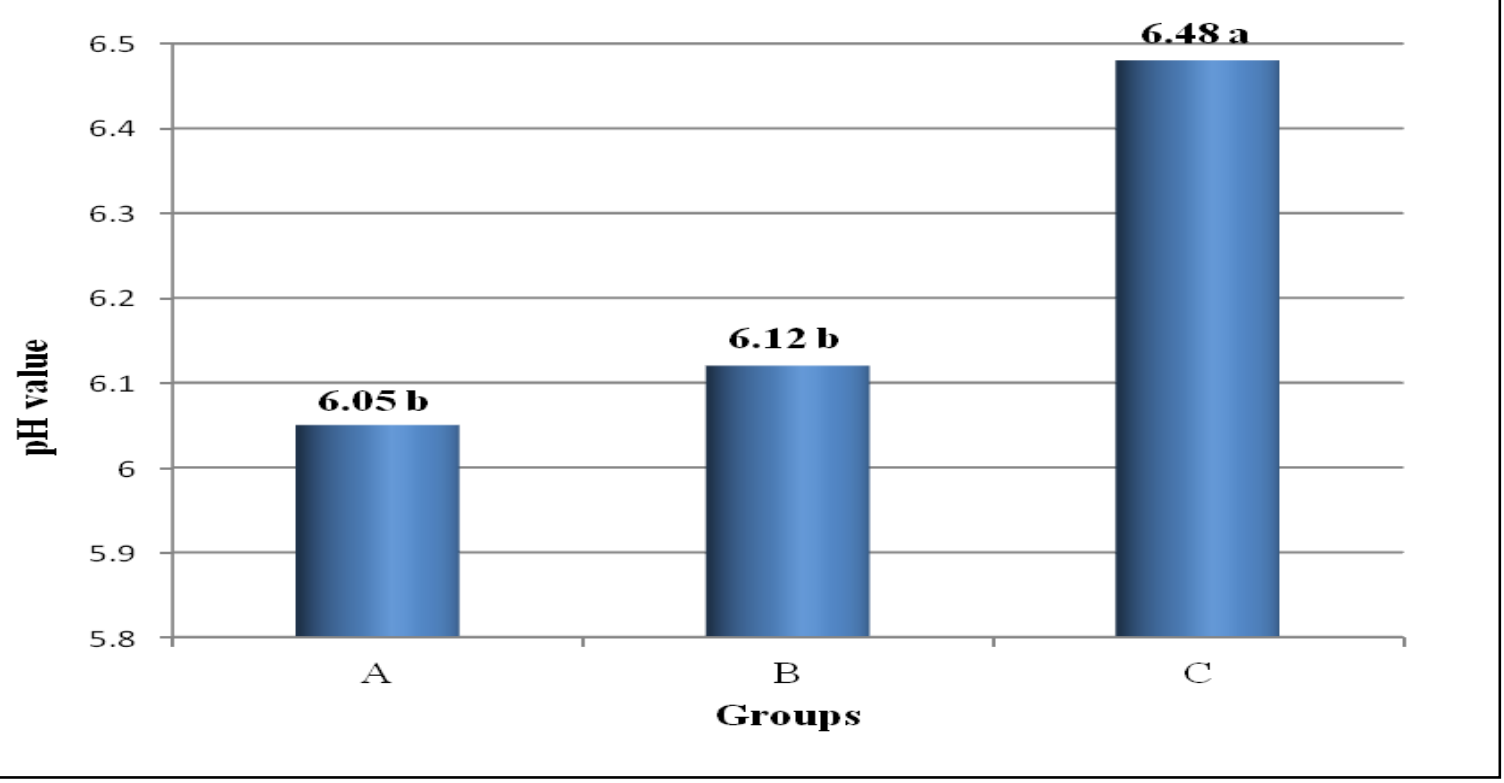

$\operatorname{LSD}(0.05)=0.2317, \mathrm{SE} \pm=0.1129$, Group $\mathrm{A}=$ Goat meat of age group 6-12 months, Group B = Goat meat of age group 13-18 months, Group $\mathrm{C}=$ Goat meat of age group $>18$ months

Figure 2. pH value of goat meat of different age groups 


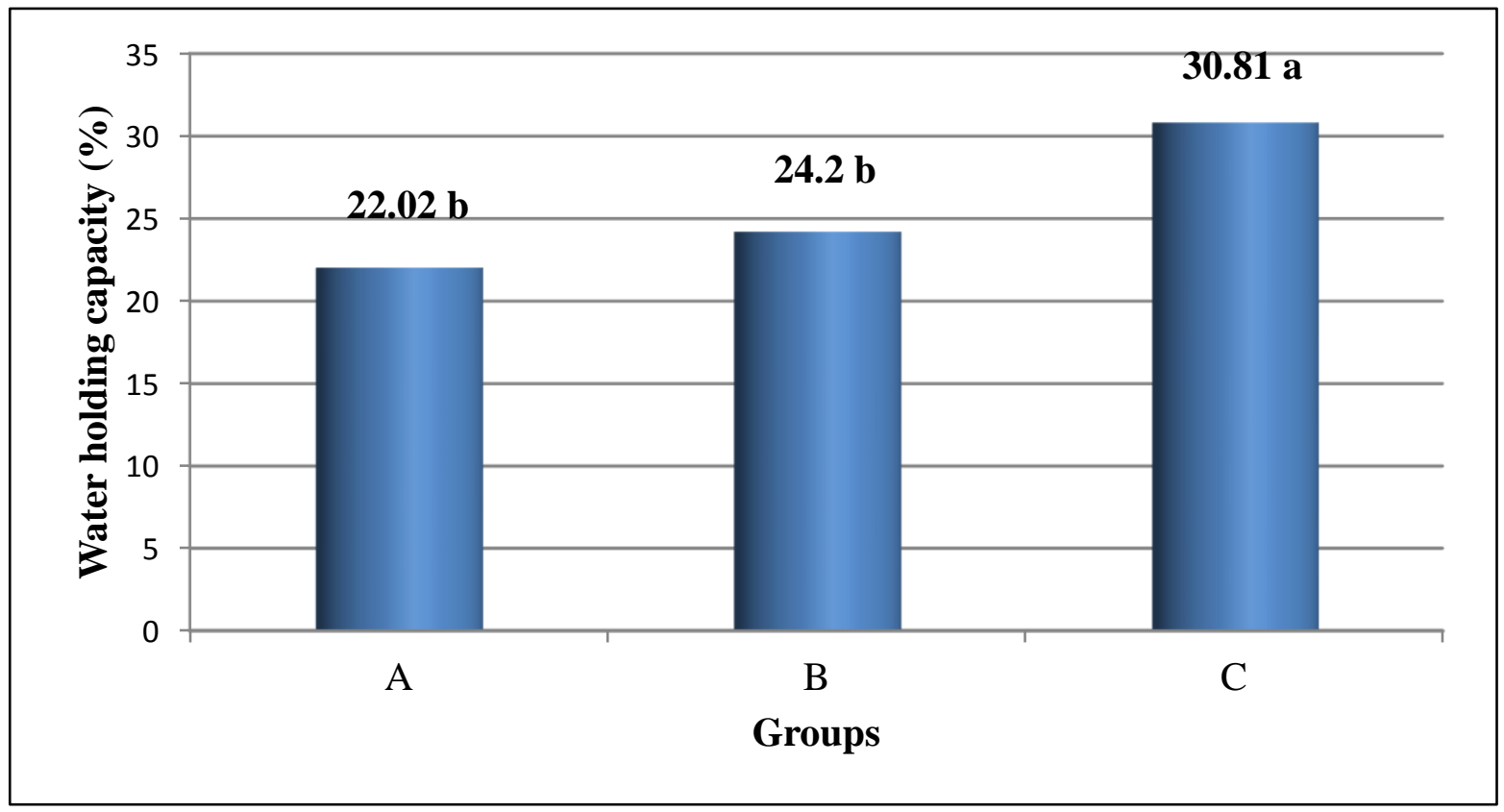

$\operatorname{LSD}(0.05)=3.1889, \mathrm{SE} \pm=1.5542$, Group $\mathrm{A}=$ Goat meat of age group 6-12 months, Group B = Goat meat of age group 13-18 months, Group $\mathrm{C}=$ Goat meat of age group $>18$ months

Figure 3. Water holding capacity $(\%)$ of goat meat of different age groups

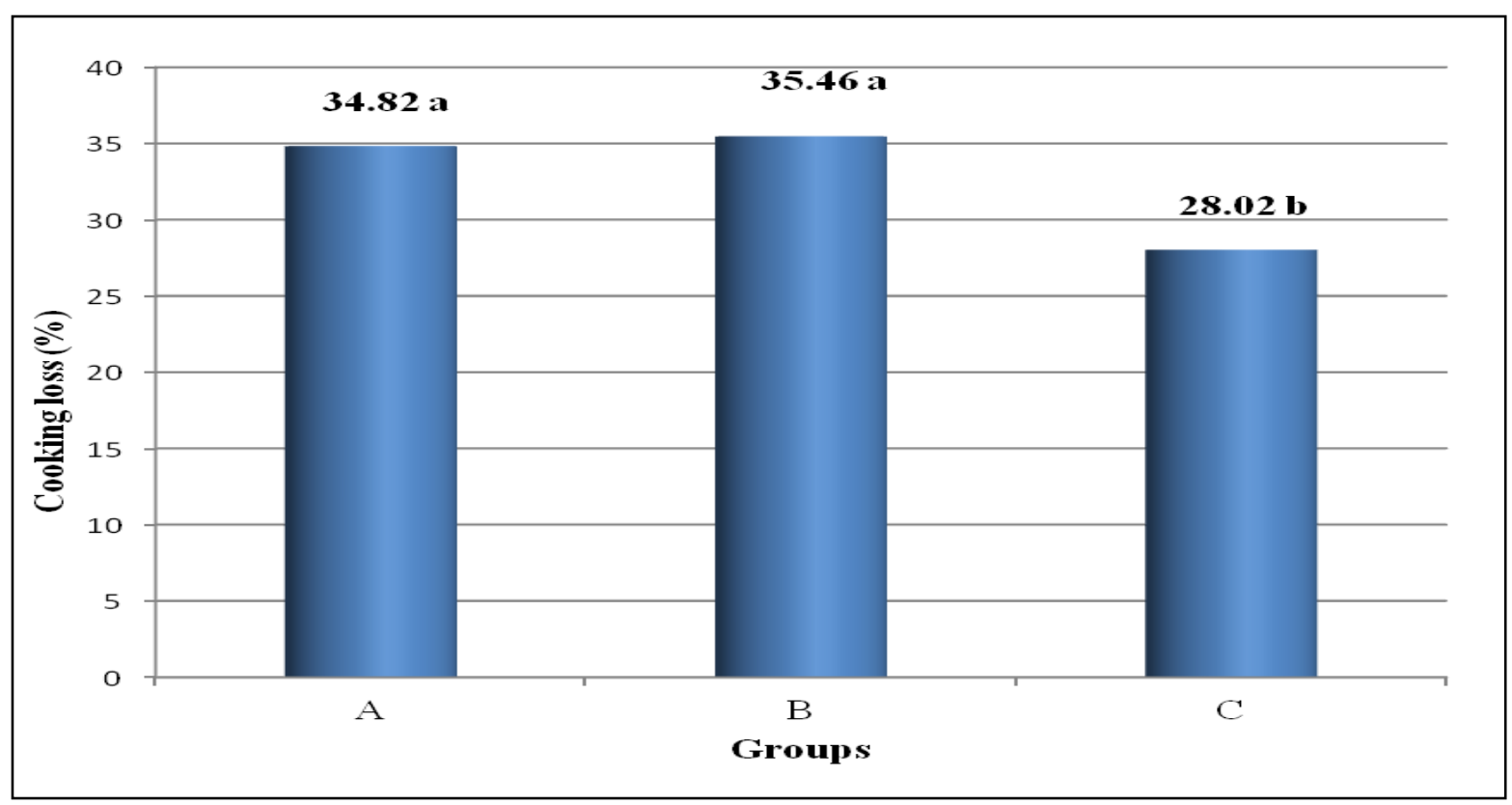

$\operatorname{LSD}(0.05)=2.66, \mathrm{SE} \pm=1.30$, Group $\mathrm{A}=$ Goat meat of age group 6-12 months, Group B = Goat meat of age group 13-18 months, Group $\mathrm{C}=$ Goat meat of age group $>18$ months

Figure 4. Cooking loss (\%) of goat meat of different age groups 


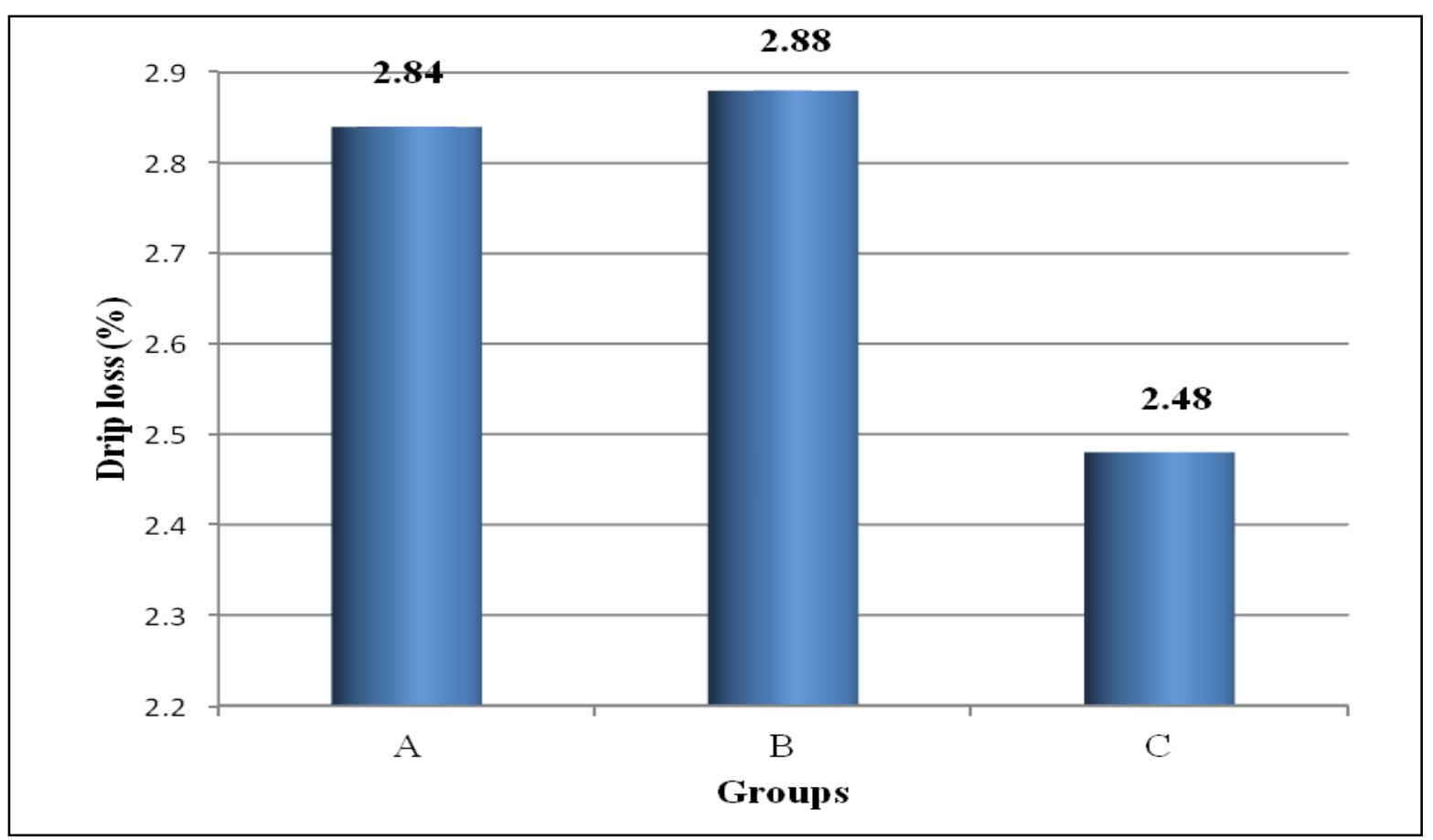

Group A = Goat meat of age group 6-12 months, Group B = Goat meat of age group 13-18 months, Group C = Goat meat of age group $>18$ months

Figure 5. Drip loss $(\%)$ of goat meat of different age groups

Table 1. Correlation matrix (Pearson) between glycogen and physical characteristics of goat meat

\begin{tabular}{|c|c|c|c|}
\hline \multirow{2}{*}{ Attributes } & \multicolumn{3}{|c|}{ Goat meat of age group } \\
\cline { 2 - 4 } & $6-12 \mathrm{~m}$ & $13-18 \mathrm{~m}$ & $>18 \mathrm{~m}$ \\
\hline Glycogen $\times \mathrm{Ph}$ & $-0.1135^{\mathrm{ns}}$ & $-0.1775^{\mathrm{ns}}$ & $0.0243^{\mathrm{ns}}$ \\
\hline Glycogen $\times$ Water holding capacity & $-0.2915^{\mathrm{ns}}$ & $-0.0542^{\mathrm{ns}}$ & $-0.0157^{\mathrm{ns}}$ \\
\hline Glycogen $\times$ Cooking Loss & $-0.3658^{\mathrm{ns}}$ & $0.6407^{\text {* }}$ & $0.2353^{\mathrm{ns}}$ \\
\hline Glycogen $\times$ Drip Loss & $0.0846^{\mathrm{ns}}$ & $0.2780^{\mathrm{ns}}$ & $0.0236^{\mathrm{ns}}$ \\
\hline
\end{tabular}

*Significant $=\quad \mathrm{P}<0.05, \mathrm{~ns}$ Non-significant $=\mathrm{P}>0.05$

\section{Discussion}

The present study was carried out to evaluate glycogen level and its influence on physical characteristics of goat meat of different age groups i.e. group A (6-12 m; age), $\mathrm{B}(13-18 \mathrm{~m}$; age) and C (>18 m; age). The average glycogen level was found to be slightly higher in group B (17.79 \pm 0.77 $\mathrm{mg} / \mathrm{g}$ ) as compared to that of group A $(17.55 \pm 0.66 \mathrm{mg} / \mathrm{g})$. The differences among them were non-significant $(\mathrm{P}>0.05)$. However, goat meat of both of these groups (A and B) appeared to have significantly $(\mathrm{P}<0.05)$ greater glycogen level than that of group C $(9.56 \pm 0.40 \mathrm{mg} / \mathrm{g})$. The results of present study disagreed with the findings of [21], who found higher $(\mathrm{P}<0.01)$ muscle glycogen in old (24 to $30 \mathrm{~m}$ of age) vs. young (6 to $12 \mathrm{~m}$ of age) goats. While, [22] supported the present results, they reported that the old animals have lower reserve of glycogen than that of younger. In another study [23] observed that eight month old lambs appeared to have greater glycogen level than that of 22 month old sheep. Nevertheless, the concentrations of glycogen in goat meat observed in the present study are in a range of findings 
reported by [4] that the muscles which produce meat with normal $\mathrm{pH}$ contain about $10-20 \mathrm{mg} / \mathrm{g}$ glycogen. Moreover, any type of pre-slaughter stress decreases the glycogen reserves in the muscles [24]. Whilst, regular exercise was known to increase the level of glycogen in the muscle of a variety of animals $[25,26]$.

In the present study the average $\mathrm{pH}$ value of goat meat was found to be higher $(\mathrm{P}<0.05)$ in group $\mathrm{C}(6.48 \pm 0.08)$ as compared to group A $(6.05 \pm 0.07)$ and B $(6.12 \pm 0.08)$. These results are appeared to be similar in trend as observed for glycogen level observed in present study. However, the relationship of glycogen v/s $\mathrm{pH}$ remained negative in goat meat of age group A (6-12 months) and B (13-18 months) and positive in group $\mathrm{C}$ (>18 months). Regardless, glycogen level in goat meat of different age groups revealed positive/negative correlation with $\mathrm{pH}$ value, but it did not show any significant influence on it. It is of interest to note that after slaughter of animal, there could be cessation of oxygen supply to muscle cells due to failure of blood circulatory system [4]. As a consequence, aerobic glycolysis is no longer possible and anaerobic glycolysis takes over (Romans et al., 2001), resulting in accumulation of lactic acid in muscle $[27,28]$, which inturn may decline $\mathrm{pH}$ value of meat. Moreover, the rate of muscle $\mathrm{pH}$ decline and the time required to reach its final ultimate $\mathrm{pH}(\mathrm{pHu})$ is highly variable in goat meat and it based on breeds, but averages at $\mathrm{pH}$ of 6.0 [29]. The concentration of glycogen observed in the present study indicates that process of glycolysis occurred in goat meat was not enough to decline the $\mathrm{pH}$ to its ultimate level. However, present results are in line with the work of [30] who observed $\mathrm{pH}$ value of goat meat in between 6.02 to 6.62 . Similarly in another study the average $\mathrm{pH}$ value of meat of 90 and 180 days kids was observed as $6.0 \pm 0.14$ and $6.03 \pm 0.11$, respectively [31]. The results of present study are also in accordance with those found by [32] who reported that the mean
$\mathrm{pH}$ value of goat meat of age $<7 \mathrm{~m}$ was $6.28,8-10 \mathrm{~m} 6.30$ and $>11 \mathrm{~m} 6.34$.

The influence of glycogen on WHC of goat meat of group A, B and C was found to be inverse in the present study. But it was not statistically countable $(\mathrm{P}>0.05)$. The average WHC of goat meat appeared comparatively higher $(\mathrm{P}<0.05)$ in group $\mathrm{C}$ $(30.81 \pm 0.75 \%)$ than that of group B (24.2 $\pm 0.77 \%)$ and $\mathrm{A}(22.02 \pm 0.45 \%)$. It could be noted that in the present study goat meat of group $\mathrm{C}$ also indicated higher $\mathrm{pH}$ value and the muscle that maintain a high $\mathrm{pH}$ could exhibit a greater WHC due to water that tightly bound to protein [27]. It has been reported that WHC has significant correlation with $\mathrm{pH}$ [33] which directly depends upon depletion of glycogen. Moreover, the glycogen level was not found to be significantly affected in the present study. However, present result of WHC of group C goat meat is relatively similar to that of observed by [7] in meat of 60 and 90 days old kids (30.5\%). According to another study conducted by [31], it was recorded with an average of $24.34 \pm 0.43$ and $24.01 \pm 0.95 \%$ of 90 and 180 days kids meat, respectively which appeared to be relatively similar to that of observed in group B goat meat in the present study. The findings of [30] Rodrigues et al., (2011) supported the present study, they reported the WHC of goat meat in between 22 to 30 $\%$. Variable results of WHC could be attributed with age of goat as it has significant effect on the WHC of the meat [34].

The influence of glycogen on cooking loss of goat meat of group A was found to be inverse and in group $\mathrm{B}$ and $\mathrm{C}$, it was positive in the present study. Further significant $(\mathrm{P}<0.05)$ relationship between glycogen and cooking loss was found to be in goat meat of group B. The average cooking loss in goat meat of group B (35.46 $\pm 0.79 \%)$ was relatively similar $(\mathrm{P}>0.05)$ to that of in group A $(34.82 \pm 0.61 \%)$ goat meat. However, cooking loss in both of these groups ( $\mathrm{A}$ and $\mathrm{B}$ ) were significantly $(\mathrm{P}<0.05)$ higher than that of group $\mathrm{C}(28.02$ 
$\pm 0.83 \%$ ) goat meat. It could be argued that cooking loss in meat is assumed to be a loss of water that muscles originally contained and could be attributed with denaturation/coagulation of myofibrillar and sarcoplasmic proteins, when meat is applied heating temperature $\geq 65^{\circ} \mathrm{C}$. At cooking temperature $65^{\circ} \mathrm{C}$, the cooking loss was reported to be about $30 \%$ and at $80^{\circ} \mathrm{C}$ over $40 \%$ [4]. Moreover, the fall in $\mathrm{pH}$ value could result in poor water holding capacity of myofibrillar muscle protein and in incline condition of $\mathrm{pH}$, the vice versa. Muscle with low water holding capacity appeared to be with higher drip and cooking losses and inverse in case of high WHC [35]. In another study the increase in cooking loss had been attributed with decline in $\mathrm{pH}$ value [36]. Similarly, the cooking loss in present study was found to be in similar range of [4]. However, present results more or less are in a similar range of that of analyzed by [30] for cooking loss in goat meat (33.34 to $35.85 \%$ ). Whilst, [32] also supported the results of presents study who observed the cooking loss as $38.72 \pm$ $0.60 \%$ of goat meat slaughtered at age of < $7 \mathrm{~m}, 35.77 \pm 0.86 \%$, of $8-10 \mathrm{~m}$ and 33.40 $\pm 1.13 \%$ of $>11 \mathrm{~m}$ of age.

In the present study the drip loss was directly related with glycogen level of goat meat of group A, B and C. However, their relationship was found to be very week/week and not statistically countable $(\mathrm{P}>0.05)$. It is of interest to note that drip is a dilute solution exude/purge of sarcoplasmic protein attributed with denaturation of muscle protein due to fall in $\mathrm{pH}$ [4], sarcomere shortening [28] and myosin degeneration, resulting shrinkage of myofibrillar components which inturn expels the resultant fluid into extracellular space [4, 37]. Whilst, also supported the results of presents study who observed the lower ultimate $\mathrm{pH}$ results in a greater drip loss. Further, [22] reported that the faster rate of breakdown of ATP in muscle results more rapid onset of rigor mortis and the greater the release of fluid from the muscles. However, the average drip loss was found to be relatively similar $(\mathrm{P}>0.05)$ in goat meat of group A $(2.84 \pm 0.19 \%)$, B $(2.88 \pm 0.39 \%)$ and $\mathrm{C}(2.48 \pm 0.19 \%)$ in the present study. Moreover, the results are found to be in line with that of reported by [38] in goat meat $(2.35 \pm 0.11 \%)$. While in another study the drip loss was recorded higher with an average of $4.93 \pm 0.16 \%$, $4.02 \pm 0.10 \%$ and $4.06 \pm 0.14$ in goat meat of age group of $\leq 7 \mathrm{~m}, 8-10 \mathrm{~m}$ and $\geq 11 \mathrm{~m}$, respectively [32] than that of observed in present study.

\section{Conclusion}

On the basis of findings of present investigation it could be concluded that the glycogen level, cooking loss, drip loss, $\mathrm{pH}$ value and WHC were resulted relatively similar $(\mathrm{P}>0.05)$ in goat meat of age group 6-12 and 13-18 m, but of these groups, were significantly $(\mathrm{P}<0.05)$ different from that of age groups $>18 \mathrm{~m}$. Regardless physical sensory characteristics of goat meat of age 6-12m and 13-18 m, were statistically nonsignificant, the later age group found to rich than that of former age group, and concluded to be better among all age groups of goat meat under present study.

\section{Authors' contributions}

Conceived and designed the experiments: S Fazlani, AS Magsi \& GB Khaskheli \& AA Khaskheli, Performed the experiments: S Fazlani, Analyzed the data: GS Barham, Contributed reagents/ materials/ analysis tools: HN Fazlani, Wrote the paper: AA Khaskheli.

\section{References}

1. Khan BB \& Issani GB (1994). Breeds and types of livestock in Pakistan. In: Animal Husbandry (S.I. Shah Ed.2 ${ }^{\text {nd }}$ ) National Book foundation Islamabad: 53-86.

2. Nelson DL \& Cox MM (2005). Lehninger principles of biochemistry. ( $4^{\text {th }}$ Ed:). New York: W.H. Freeman and Company: 543-544.

3. Roach PJ (2002). Glycogen and its metabolism. J Current Molec Med 2: 101-120.

4. Warriss PD (2000). The effect of live animal handling on carcass and meat 
quality. Hand book of Meat Science. School of Vet. Sci. Uni of Bristol UK: 144-146.

5. Madruga MS, Medeiros EJL, Sousa WH, Cunha MGG, Filho JMP \& Queiroga PCRS (2009). Chemical composition and fat profile of meat from crossbred goats reared under feedlot systems. J Rev Bras Zootec 38: 547-552.

6. Muchenje V, Dzama K, Chimonyo M, Strydom PE, Hugo A \& Raats JG (2009). Some biochemical aspects pertaining to beef eating quality and consumer health: A review. Food Chem 112: 279-289.

7. Pena F, Bonvillani A, Freire B, Juarez M, Perea J \& Gomez G (2009). Effects of genotype and slaughter weight on the meat quality of CriolloCordobes and Anglonubian kids produced under extensive feeding conditions. J Meat Sci 83: 417-422.

8. Warren HE, Scollan ND, Nute GR, Hughes SI, Wood JD \& Richardson RI (2008). Effects of breed and a concentrate or grass silage diet on beef quality in cattle of 3 ages. II: Meat stability and flavour. J Meat Sci 78: 270-278.

9. Wachholz D, Kauffman RG, Henderson D \& Lockner JV (1978). Consumer discrimination of pork colour at the market palace. J Food Sci 43: 1150-1152.

10. Jeremiah LE (1984). A note on the influence of inherent muscle quality on cooking losses and palatability attributes of pork lion chops. Candi. J Anim Sci 64: 773-775.

11. Newton KG \& Gill CO (1981). The microbiology of DFD fresh meat: a review. J Meat Sci 5: 223-232.

12. Muchenje V, Dzama K, Chimonyo M, Strydom PE \& Raats JG (2008). Sensory evaluation and its relationship to physical meat quality attributes of beef from Nguni and Bonsmara steers raised on natural pasture. J Anim Sci 2: 1700-1706.
13. Taylor AA \& Shaw BG (1977). The effect of meat $\mathrm{pH}$ and package permeability on putrefaction and greening in vacuum packed beef. $J$ Food Tech 12: 515-521.

14. McMillin, KW \& Brock AP (2005) Production practices and processing for value added goat meat. J Anim Sci 83: 57-68.

15. Santos VAC, Silva AO, Cardoso JVF, Silvestre AJD, Silva SR, Martins C \& Azevedo JMT (2007). Genotype and sex effects on carcass and meat quality of suckling kids rotected by the PGI "Cabrito de Barroso". J Meat Sci 75: 725-736.

16. Kemp A, Adrienne JM \& Heijningen KV (1953). A colourimetric micromethod for the determination of glycogen in tissues. J Biochem 3: 646656.

17. Ockerman HW (1985). Quality control of post mortem muscle tissue (13 ${ }^{\text {th }}$ Ed:).The Ohio State University, Colombus, $\mathrm{OH}: 212-220$.

18. Wardlaw FB, McCaskill LH \& Acton JC (1973). Effect of postmortem muscle changes on poultry meat loaf properties. J Food Sci 38: 421-423.

19. Kondaiah N, Anjaneyulu ASR, Rao KV, Sharma N \& Joshi HB (1985). Effect of salt and phosphate on the quality of buffalo and goat meat. $J$ Meat Sci 15:183-192.

20. Sen AR, Santra A \& Karim SA (2004). Carcass yield, composition and meat quality attributes of sheep and goat under semi arid conditions. J Meat Sci 66: 757-763.

21. Kannan G, Kouakou B, Terrill TH \& Gelaye S (2003). Endocrine, blood metabolite, and eat quality changes in goats as influenced by short-term, pre slaughter stress. J Anim Sci 81: 14991507.

22. Gracey JF, Collins DS \& Huey RJ (1999). Anatomy, meat composition and quality. $J$ Meat hygiene 10: 600612. 
23. Ponnampalam EN, Hopkins DL, Bulter KL \& Warner RD (2008). Muscle glycogen in sheep: Genotype and gender effects. J Proc Aust Soc Prod 27: 105-117.

24. Grandin T \& Gallo M (2007). Welfare requirements of handling facilities. In: Farm animal housing and welfare, Netherlands. J. Anim. Sci 3: 137-149.

25. Tan MH, Bonen A, Watson WW, Hood D, Sopper M, Curries D, Balcastro AN \& Pierce G (1984). Muscle glycogen repletion after exercise in trained normal and diabetic rats. J Appl Phys 57: 1404-1408.

26. Topliff DR, Poter GP, Krieder JL, Dietson TR \& Jessup GT (1985). Diet manipulation, muscle glycogen metabolism and aerobic work performance in the equine. Proceeding $9^{\text {th }}$ Equine Nutri \& Physi Sci synp: 224229.

27. Aberle ED, Forrest JC, Gerrard DE \& Mills EW (2001). Principles of meat science. J Muscle Food 17: 516-524.

28. Honikel KO (2004). Chemical and physical characteristics of meat $\mathrm{pH}$ measurement. Federal Research Centre for Nutrition and Food, Kulmbach, Germany: 75-80.

29. Karakaya M, Saricoban C \& Yilmaz MT (2006). The effect of mutton, goat, beef and rabbit meat species and state of rigor on some technological parameters. J Muscle Food 17: 56-66.

30. Rodrigues L, Goncalves HC, Medeiros BBL, Martins MF, Komiyama CM \& Canizares MC (2011). Effect of genotype, finishing system, and sex on physiochemical characteristics of goat meat. J Food Sci Tech 31: 992-997.
31. Lendzion, KP, Niedziolka $\mathrm{R} \&$ Borkowska T (2009). Some carcass traits and physicochemical composition of White Improved breed goat kids. J Anim Sci 4: 425-431.

32. Arain MA, Khaskheli M, Rajput IR, Rao S, Faraz S, Fazlani SA, Devrajani K \& Umer M (2010). Examination of physical properties of goat meat. Pak J Nutr 9: 422-425.

33. Laskar SK \& Nath DR (1998). Studies on certain qualitative aspects of goat meat marketed in Guwahati city. Ind $J$ Anim Prod Manag 14: 217-218.

34. Bonvillani A, Pena F, Domenech V, Polvillo O, Garcia PT \& Casal JJ (2010). Meat quality of CriolloCordobes goat kids produced under extensive feeding conditions. Effects of sex and age/weight at slaughter. J Spanish Agri Res 8: 116125.

35. Bruce HL, Stark JL \& Beilken SL (2003). The effect of finishing diet and post mortem ageing on the quality of M. longissimus thoracis of the electrically stimulated Brahman steer carcasses. J Meat Sci 67: 261-268.

36. Lawrie RA (1991). Meat Science. (5th Ed:) Pergamon Press Plc, Oxford, U.K: 35-40.

37. Hui YH, Nip WK, Roger RW \& Young OA (2001). Post mortem muscle chemistry. Meat science and application ( $\left.3^{\text {rd }} \mathrm{Ed}:\right)$ : $60-65$.

38. Sitz BM, Calkins CR, Feuz DM, Umberger WJ \& Eskridge KM (2005). Consumer sensory acceptance and value of domestic, Canadian and Australian grass-fed beef steaks. $J$ Anim Sci 83: 2863-2868. 